Makale Geliș | Received: 01.09.2020.

Makale Kabul| Accepted: 28.09.2020.

DOI: $10.18795 /$ gumusmaviatlas. 788925

Mavi Atlas, 8(2)2020: 517-525

Araştırma Makalesi|Research Article

\begin{abstract}
Mustafa AYYILDIZ
Dr. Öğr. Üyesi| Assist. Prof. Dr.

Gümüşhane Üniversiyesi, Edebiyat Fakültesi, Türk Dili ve Edebiyatı Bölümü, Gümüşhane-TÜRKIYY Gumushane Üniversity, Faculty of Letters, Department of Turkish Language and Literature, Gumushane-TURKEY

ORCID: 0000-0002-6594-3080

mustafaayyildiz29@hotmail.com
\end{abstract}

\title{
Yeni Edebiyat ve Nesiller
}

\section{Öz}

Toplumların hayatı dikkate alındığında, sosyal nizamın ve hedeflerin şekillenmesinde fertlerden ziyade nesillerin etkili olduğu görülür. Nesiller çoğunlukla bir ekolün, akımın yaratıcısı olarak vücut bulurlar. Ekollerde olduğu gibi bir tezantitez durumu onları diğerlerinden keskin çizgilerle ayırır. Nesil için söylenenler özel manada edebî çevreler için de geçerlidir. Edebî nesil ise edebiyatın sahasına ait, edebî açıdan kıymetli mevzular etrafında şekillenen nesillerin, özel bir sahaya ad vermesidir. Edebi neslin şekillenmesinde devir, mektepler, Tanzimat sonrası batılı örnekler faktörler rol oynar. "Batılılaşma Devri", "Arayışlar Devri", "Modern Edebiyat" gibi birçok isimlendirilmeye tabi tutulan son yüz elli yıllık edebiyatımızda en dikkati çeken husus, oldukça fazla ekol, isim, akım ve dolayısıyla nesle yer vermesidir. Tanzimat birinci grup nesli; Şinasi, Namık Kemal ve Ziya Paşa ekibinin öncülüğünü yaptığı nesildir. Tanzimat nesli devrin fikir akımlarına öncülük yapmış, bütün hamlelerde de ilk olmuştur. Tanzimat ikinci nesli Abdülhak Hamit, Recaizade Mahmut Ekrem ve Samipaşazade Sezai'nin temsil ettiği, "Hamit-Ekrem-Sezai" Mektebi de denilen nesildir. $\mathrm{Bu}$ nesil her şeyden önce sosyal ve politik meselelere kayıtsız kalır. Onların zaviyesinde sanat, sosyal faydayı değil ferdi 1stırapları ele alan estetik yeterliği gaye edinen bir sahadır. Ara nesil modern edebiyatın üçüncü nesli Nabizâde Nazım, Mehmet Celal, Mehmet Ziver, Fazlı Necip gibi edebiyat tarihinde çok parlak yer edinemeyen isimlerden oluşur. Bu nesil, duyuş tarzı ve üslup sahasında edebiyatın çehresine değişiklik getirmeyi başaran 25-30 kişilik bir gruptur. Devrin en dikkate değer tarafı, gazetecilik yerine dergiciliği oldukça iyi bir aşamaya getirmiş olmasıdır. Modern edebiyatın dördüncü nesli olarak yer alan Servet- i Fünûn nesli, son yüz elli yılda oldukça etkili ve adından bahsettiren bir gruptur. Bu devir sanatkârları gibi eserleri de hastalıklı ve solgun bir mahiyet arz eder.

Anahtar Kelimeler: Edebi Nesil, Cumhuriyet Dönemi, Tanzimat Dönemi, Servet- i Fünûn, Yeni Türk Edebiyatı.

\section{New Literature and Generations}

\begin{abstract}
When life of societies is taken into consideration, it is seen that generations rather than individuals are effective in shaping social order and goals. Generations generally come into existence as creator of a school, a trend. As in the schools, a thesis-antithesis situation sharply separates them from others. In this respect, the harmony of language understanding ensures the continuity of a previously developed understanding. What is said for the generation is also valid for to literary circles in a special sense. The literary generation, on the other hand, is the name given to a special field by generations that are formed around literary precious issues. In shaping the literary generation, the period, schools, post-Tanzimat western examples play a role. The most striking point in our literature of the last hundred and fifty years, which was subjected to many names such as "The Age of Westernization", "The Age of Searches", "Modern Literature", is that it includes a lot of schools, names, movements and therefore generations. First generation of Tanzimat is that it was led by the team which was composed of Şinasi, Namik Kemal, and Ziya Pasha. The Tanzimat generation pioneered the intellectual currents of the era and was the first in all moves. The second generation of Tanzimat is the generation also called "Hamit-Ekrem-Sezai" School, represented by Abdülhak Hamit, Recaizade Mahmut Ekrem and Samipaşazade Sezai. This generation is above all indifferent to social and political issues. In their perspective, art is a field that aims at aesthetic competence that deals with individual suffering, not social benefit. The third generation of the intermediate generation of modern literature consists of names such as Nabizâde Nazım, Mehmet Celal, Mehmet Ziver and Fazlı Necip who could not have a very bright place in the history of literature. This generation is a group of 25-30 people who succeeded in bringing a change to the face of literature in the field of perception and style. The most remarkable aspect of the era is that it brought magazine publishing rather than journalism to a very good stage. Servet-i Fünûn generation, which is the 4th generation of modern literature, is a very influential group that has made a name for itself in the last hundred and fifty years. Like the artists of this period, its works were also sickly and pale.
\end{abstract}

Keywords: Literary generation, Republic Period, Tanzimat Period, Servet-i Fünûn, New Turkish Literature. 


\section{Giriş}

Insanlık tarihi çok çeşitli medeniyetlere sahne olmuştur. Fakat bunlardan hiçbiri ebedî olamamıştır. Çünkü bu medeniyetler, dinamizminin zirvesine yükseldikten sonra inişin ve inkırazın elinden kendini kurtaramamıştır. Kâinatta insanın kaderine paralel olarak devletlerin iniş, çıkış ve tükenişi de hiç şüphesiz mukadderdir. Bu nedenle tarihe ve istikbale bu açıdan bakmak isabetli olur zannediyorum.

Türk medeniyet tarihi bilinen en son dönüşünü yaklaşık 200 yıllık başlangıç kabul edilen, modern dönemin öncesinde yaşamıştır. Osmanlı nâmıyla anılmayı hak etmiş olan İslamî medeniyetimiz, bütün bitişler gibi çok yönlü krizler ve -diğer tükenişlerden farklı olarak- çok uzun bir nekahat devresi yaşamıştır. Şüphesiz öyle miraslar bırakmıştır ki o ölü gibi mirastan, yepyeni bir medeniyet kurulacağını beklemek safdillik değildir.

Osmanlının teslimiyeti veya hamlesi farklı şekillerde ele alınmış ve yorumlanmıştır. Ancak bu inkırazı anlamak için daha önceye bakmak icap eder. Böylece yeni bir başlangıca neden gelindiğini daha iyi anlamış oluruz. Osmanlı medeniyeti 1700'lü yıllara kadar top- yekûn bir olgunluk -zaaflarıyla birlikte- yaşadı. Dünya yüzünde uzun bir hâkimiyeti yalnız başına tesis etti. Onların bu dirayeti millî bir psikolojiyi beraberinde getirdi ve dışlarında olabilecek hiçbir şeyi tasavvur edemediler, dikkate almadılar. Zaten tek rakip görünen Batı, yüzyıllarca skolastik hummadan ıstırap çekmiş, uzun bir köhnelik yaşamış ve bitmişti. Osmanlıyı sona yaklaştıran, kendi bünyesinden kaynaklanan çözülme kadar -belki de daha fazla- Batı'nın uyanışı ve dirilişiydi. Hep olduğu gibi biri ölürken diğeri ayağa kalkıyordu.

Öncelikle Tanzimat'a kadar Osmanlıda neler yaşandı ona bakmak lazım: Medeniyet topyekûn bir hamledir. Osmanlıda, idareden ilmiyeye kadar çözülme başladığında dirayetsiz -hatta daha ileri- idareciler, padişahlar ve vüzera başa gelmiştir. Emanet, ehline verilmemiş ahlâkî çöküntü ve cehaletin pençesinde küflenmeye yüz tutmuştur.

Yanlışlar birbirini takip etmiş, ilmi gelişme donmuş, geniş coğrafyada otorite sarsılmış, maliye bozulup, devletin genel yapısını oluşturan askeriye laçkalaşmıştır. Daha birçok şey tarihin aydınlığında vuku bulmuştur. Yani bütün müesseseleriyle çözülüş aşama aşama gerçekleşmiştir.

Öte yanda Batı, reform ve rönesanslarıyla Doğu'dan çok farklı tam seküler bir kalkınmayı hızla yaşamış, dünya nimetlerini enine boyuna değerlendiren, tam bir hükümranlık ve sömürüyü hedefleyen sanayi devrimini yaşamıştır. Öyle bir dünya kurmaya başlamıştır ki Doğu'ya hem yabancı hem de onu cazibesine çeken bir dünyadır bu. Teferruat bir yana, Batı'nın yükselişi, hâkimiyetini dünyevi olarak tesis ederken Doğu bir uhrevî medeniyetti. Sadece dünyaya yönelik olmanın hesabını yapmak onu şaşırttı. Bu nedenle dikte edilen yeniliğe kapalı olduğumuz iddiaları çürüktür. Bizi şaşırtan zıt medeniyetlerin dünyayı kasıp kavurmasıdır. Doğu çelişkileri her sahada, özellikle de zihinlerde yaşanmaya başladı. Bu şiddetli bir çelişkiydi. Hayatta kalmak, hatta yeniden toparlanmak sekülerleşmeyi gerektiriyordu. Direnmeler başlayınca ikilemler ve çatlaklar başladı. Bununla beraber sentezleme denendi -çoğunlukla- ama olumlu sonuç alınamadı.

Bir taraftan tam bir Batılı medeniyet tesisini çözüm olarak gören aydınlar gayret içine girdi. Öte yandan batılılaşmayı dünya görüşlerine ters gören, sekülerleşmeyi zihinlerine sindiremeyen düşünür ve idareciler başka çözümler aramayı denedi. Umumî aydın kitlesi hep bir sentez peşinde koştu. Ancak medenî oluşum yamama gayretleri kabul etmiyordu. Bütün bu oluşumlar hâlâ yeni gibi Türk fikir dünyasında yaşamaktadır. 200 yıldır bütün değişimine ve oluşumuna rağmen hiçbir şey tam olarak değişmiş değil. Yani kriz hâlâ bir yanıyla başladığı yerde duruyor.

Edebiyat ne insandan ne de insanın birlikteliği olan sosyal ortamdan, düşünceden ve hayattan ayrı düşünülemeyeceği için bütün olup bitenden yeterince, hatta haddinden fazla nasibini aldı. Batı ve Doğu'nun bir türlü uzlaşamadığı krizi en çok da edebî yapımız hissetti, bitmeyen, 
biteceğe benzemeyen bir çelişki başladı. Bu dönüşüm krizle başladı daha doğrusu bir türlü çözüme varamayan kriz başlamış oldu.

Öncesi değişim teşebbüsleri olmakla beraber Tanzimat'ı başlangı̧̧ kabul ediyoruz. Beslendiği kaynaklar itibariyle Kur'anî bir doku arz eden Osmanl, sevgi ve gönül medeniyetiydi. Karşısında mecburi bir izdivaca zorlandığı Batı ise aklın, hesabın, faydanın ve insanın medeniyetiydi. $\mathrm{Bu}$ yöneliş mecburiyete dönmüştü. En yanlışı bile iyi niyetin ürünü olduğuna inandığım sslahatlar, düzenlemeler ve bazen gafleti aşan kararlar bu başlangıcın uzantısı oldu. Tanzimat gerekli miydi? Bu soru artık anlamsızdır. Çünkü Tanzimat mecburiyetti.

Uzun yıllar sürdürdüğü hâkimiyeti sona ermiş hantal bir ülke, onu idare eden idareciler, isyanlar, yenilgiler, ekonomik dengesizlikler, kapitülasyonlarla yarı sömürü bir maliye, adaletsiz mahkemeler, medeniyet değerlerinden kopuk aydınlar, şaşkın bir halk... Bu durumda bir düzenleme manasina gelen Tanzimat gereksiz ve zamansız olamazdı. Düzenleme olmalıydı. Ama 1839 tarihli yapılan düzenleme mi? İşte mesele burada başlıyor. Getirilen düzenlemeler ya yergiye ya yetersizliğe ya da övgüye muhatap oldu. O gün bir şeyler yapılmalıydı. Yapıldı ama ne ihtiyaçlara cevaptı bunlar ne de bizim içindi. Tanzimat Fermanı maddeleri bunu açıkça beyan ediyor. Tükenişin, teslimiyetin kaçınılmaz beyanıydı bunlar. Alış tarzı mı suçlu alınış tercihleri mi suçlu? Bunlar uzun uzun irdelenmiştir. Ancak çözüm ve fikir birliği hâlâ söz konusu değil. Bir millet "kendi olamayacak kadar" değişmeli miydi? Bu yapıldı. Başka çıkar yol, başka çözüm bulamayıştı bu. Bu yapılanlar şaşkınlığın, telaşın neticesiydi. Sonrası! Sonrası bağnazca sarılma oldu. Medeniyetler model alırlar, alışveriş tabiidir, deneyimden faydalanmamak ise ahmaklıktır. Ama taklit ancak çılgınlık, aptallık ve şaşkınlıktır. Ne yapılabilirdi? Model deneyim alınır, gözlenir, kendi şartlarına, yerli kaynaklarına, ihtiyaçlarına paralel, bünyesine uygun, yepyeni, farklı bir yekûn kurulabilirdi. Topyekûn farklı... Kendinden, kendisi için, kendine göre, gerektiği kadar. Bütün bunlar yapılmalıdı. Yapılamadı, yaptırılmadı. Batılı olmak oldum demekle mümkün olamazdı. Hele Doğu'nun Batılılı̆̆1 oldukça zordu. Bırakın sanayi, tarım, teknolojiyi, adalet, idare, hukuku her alanda batılı olmak doğu zihniyeti için çok çok zordu ama gelinen nokta da bunu artık tartışmak gereksizdi. İstikamet, metot, idrak, azim iflas etmişti. Yeni, yepyeni, köklerinden esas olan, gerektiği gibi olan, kendi hamurunu yoğuran, kendi orijinalini kuran, her şeyde ama her şeyde topyekûn bir medeniyet tesisi yeniden mümkün olamadı... Tanzimat'ta bu bütünün bir parçasıydı. İyi kötü yuvarlak hükümler, övgü yergi peşinciliği bütün tarih ve birikim için mahsurludur. O hamlenin en azından bir deneme olmasından ders çıkarılmalıdır. Yanlış insan için olduğu gibi milletler için de tekrarı asla kabul edilemez bir şeydir. Doğruluğun tekrarı ise akıllı bir tavirdır.

Hülâsa olarak diyebiliriz ki yeni medeniyet çerçevesine giren cemiyetimizin şïri de farklılıklar göstermiştir. Teknik açıdan yenilik adına fazla bir şeyden bahsedememekle beraber üslûp, ifâde ve tema bazında kendine has bir vaziyeti yakalayabilmiştir. Eski edebiyatın ahirete yönelen yüzü, yeni edebiyatla dünyaya dönmüștür. Devrin sanatkârlarında görülen çoğu yeni hususiyetler, yeni şiir ve anlayışın mahsûlü olarak anlaşılmalıdır. Bu manada Türk edebiyatının modern dönem devirlerine -nesillerine- bakmak gerekir.

Soy, döl, döş, zürriyet, sülâle, kuşak, nesil manâlarına gelen nesil kelimesi lisan içinde kullanılırken oldukça geniş manalarda işlev görür. Terim anlamı, ortak özelliklerin bir araya getirdiği topluluğu karşılamak üzere, şu müştereklerin sonucudur:

İçtimai, siyasi ve iktisadi şartları aynı, terbiye (eğitim, yetişme) şart ve durumları aynı, endişe ve meseleleri aynı, yaşları yaklaşık olarak aynı olan kişilerin oluşturduğu topluluk nesil sayllir.

Bu tasnifte esas olan iki husus söz konusudur. Müşterek değerlerin etrafinda buluşmak ve bu beraberlikten ortak bir idrak, ruh oluşturmak. Toplumların hayatı dikkate alındığında, sosyal nizamın ve hedeflerin şekillenmesinde fertlerden ziyade nesillerin etkili olduğu görülür. Tarihi 
şekillendiren, yönlendiren -her ne kadar fertler öne çıkarılsa da- aslında nesillerdir. Her neslin kendinden önce ve kendinden sonraki nesillerle ortak yanları olacağ1 gibi onları farklı kılan özellikleri de mevcuttur (Kaplan, 1985: 5). Devirleri şekillendiren, nesilleri öne çıkaran, o nesli temsile yetkili ve yeterli şahsiyetler, her nesil için geçerlidir. Bu tabii bir yön olmakla beraber, insanların fertleri büyütme duygusundan da kaynaklanmıştır. Bu öne çıkan şahsiyetlerin neslin genel dokusunu kendilerinde bulundurması ve nesli iyi anlamak için o neslin bütün fertlerinin ayrı ayrı değerlendirilmesi gerekir.

Nesiller çoğunlukla bir ekolün, akımın yaratıcısı olarak vücut bulurlar. Ekollerde olduğu gibi bir tez-antitez durumu onları diğerlerinden keskin çizgilerle ayırır. Özellikle dil anlayışları nesilleri birbirine yaklaştıran veya uzaklaştıran bir faktördür. Bu itibarla lisan anlayışının uyumu daha önce geliştirilen bir anlayışın da devamlılığını sağlar. "Bir anlayışı, bir fikri, bir uygulamayı veya herhangi bir işi devam ettiren kişi (ya da kişiler) onu ilk başlatan(lar)ın neslinden sayılır." $\mathrm{Bu}$ kabul, zaman denilen sınırları aşarak yüklendiği aksiyona göre o neslin mensubu olmayı da mümkün kılar. Aynı ideallere sahip olmak demek, o çığırı açan insan(lar)ın neslinden olmak manasına gelir. Buradaki ilişki kan, boy anlamının yerine, aynı dünya görüşüne mensup, aynı fikirlere sahip olma ilgisiyle izahını bulur. Bu manada, Oğuz Nesli, Asım'ın Nesli, Fatih nesli, Yunus nesli gibi adlandırmalar izahını bulur. M. Kaplan'ın "tip" olarak ele aldığı destan, mesnevi, roman gibi vakaya dayalı edebî eserlerin asli kahramanlarının açtığı çığırı -küçük farklara rağmenaynı ruh ve aynı fikri taşıyan insanlar olarak görmek mümkündür. Gazi tipi, veli tipi, alp ve eren tipi bu manada değerlendirilmelidir (Kaplan, 1970: 19).

Edebî nesil ise edebiyatın sahasına ait, edebî açıdan kıymetli mevzular etrafında şekillenen nesillerin, özel bir sahaya ad vermesidir. Bu tür kendine has varlık gösteren bütün alanlar için böyle bir isimlendirme mümkündür. Dolayısıyla, nesil için söylenenler özel manada edebî çevreler için de geçerlidir. Buna göre; "İçtimai, siyasi, iktisadi şartları aynı, eğitim ve kendilerini yetiştirme durumları birbirine benzer, aynı endişe ve meseleleri paylaşan, aşağı yukarı aynı yaşlarda olan" (Kaplan, 1970: 19) ve edebiyatın herhangi bir türünde eser veren kişilerin oluşturduğu topluluklara "edebi nesil" denir.

Bir edebi neslin şekillenmesinde belli faktörler rol oynar:

1- Devir: İçinde yaşanılan idari, sosyal yapının genel tutum ve karakterleri, nesillerin şekillenmesinde etkili olur. Mesela Tanzimat nesli, siyasi anlamda Tanzimat hareketi, meşrutiyet ve Batı'yla temas aşamalarını yaşayan Osmanlının ortaya çıkardığı, adını koyduğu gibi bütün bu hareketlerle çok sıkı münasebeti olan nesildir. Servet-i Fünûn, batılı fikirler, ferdi mizaçlar yanında, Abdülhamit idaresinin ve devrinin sonucu olarak doğmuş, hayatiyetini idari yapıyla olan münasebeti doğrultusunda sürdürmüştür.

2- Mektepler: Nesiller; okul veya mektep oluşturmuş akımların veya kurumların terbiyesinden geçer ve oluşumlarının nüvesini, müştereğini buralardan alırlar. Mesela Tanzimat nesli, bir yanıyla medreseli, bir yanıyla mektepli, bir yanıyla eski (doğulu), bir yanıyla (Batılı) yenidir. Servet-i Fünûn, Abdülhamit'le olan şiddetli çatışmalara rağmen onun açtığı veya onun zamanında açılan Batılı okullardan yetişmiş insanlar topluluğudur.

3- Tanzimat Sonrası Batılı Örnekler: Tanzimat nesli düşünce adamları belirli akım ve fikirlere yönelip eserler verince, -Hamit'in romantikleri, Servet-i Fünûn'un romantizm ve sembolizm tesirinde eserler vermesi gibi- ardından gelen insanlar bu örneklere yönelmiş, ilk olanların Batılı eserleri örnek alması gibi sonradan gelenler ya kaynağından ya da kaynağı örnek alanlardan etkilenmiş, dolayısıyla ilgi alanı belli noktalarda yoğunlaşmıştır.

Edebî sahada da zirve olan isimler öne çıkmıs, kendilerinden sonra gelen insanları etkilemişlerdir. Dolayısıyla o insanların adıyla anılan nesillere de rastlamak mümkündür. Mesela, Tanzimat neslinden, vatan şairi Namık Kemal tarzında eserler verenler N. Kemal nesli, Servet-i Fünûn şiirinin öncüsü T. Fikret anlayışı ve tarzında eserler veren isimler Fikret nesli, Mehmet 
Akif tarzı ve anlayışını sürdüren isimler ya Akif nesli ya da eserlerinde öne çıkardığı, "Asım nesli" diye adlandırılmışlardır. Nesillerin oluşumunda Tanzimat sonrası farklı bir hüviyet arz eder.

Yüzyıllarca homojen bir yapı arz eden Doğu-Osmanlı toplumunda nesiller birkaç yüzyılda şekilleniyordu. Kâinatı algılayışları, mefkûreleri, şahsiyet ve ilgileri, değer yargıları, sık sık değişim yerine oldukça yavaş değişim geçiriyordu. Nehrin yatağını bulmuş şekline benzeyen Osmanlı nesilleri, edebî sahada olduğu gibi diğer sahalarda da keskin kopmaları yaşamamıstır. Halk şiiri ve edebiyatı yüzyıllarca aynı ekol, aynı terbiye ve terminoloji görünümündedir. Tekke, Âşı, Anonim gibi sınıflandırılmalara rağmen, topyekûn bir karakter oluşumunu devam ettirmişlerdir. Keza Klasik edebiyat için de aynı şeyleri söylemek mümkün. Aynı mektepler; aynı tedrisat, aynı hayat görüşünü, aynı lisanı, aynı formları doğurmuş, mesela Türkî-i Basit, Sebk-i Hindî gibi akımlar farklara rağmen değişik bir nesil oluşmasını sağlayamamıştır. Veya isimler bazında, öne çıkan Fuzûli, Bakî, Nedim, Nabî vb. isimleriyle dört yüz yll süren bir nesil görünümü arz eder.

Tanzimat edebiyatına gelince işin rengi değişir. Devirler, ekoller, okullar, lisanlar çokluğuyla ve örneklerin değişimiyle, bir nevi nesiller edebiyatı ortaya çıkar. Tanzimat, siyasi ve idari hadisesinin adıyla anılan, 1860 sonrası faaliyet gösteren batılılaşma devrinin ilk neslini oluşturur. Tanzimat neslinin ardından, Servet-i Fünûn neslinin gündemi alacağı ana kadar, bu neslin adı söz konusudur. Ancak bu arada "Ara nesil" ve ara nesilden önce Tanzimat'ı II. grup olarak da ayırıp bir nesil saymak gerekir (Kaplan, 1987: 32).

Tanzimat I. grup nesli Şinasi, Namık Kemal ve Ziya Paşa ekibinin öncülüğünü yaptığ1; yaşlarının farklılığına rağmen eğitimleri, özellikleri ve amaçları itibarı ile kurdukları ekol, açtıkları yol itibarı ile ilk nesildir. Bu nesil Osmanlı şiirine olduğu kadar, topyekûn Doğu anlayışına reaksiyon olarak doğmuştur. Eskiye tamamen zıt bir açılımın ve gelişimin başlangıcı olan bu anlayış öncelikle eskinin soyut, tecrit anlayışına tam aksi bir tavırla, sosyalleşmeyi karakterinin parçası yapmıştır. Hayat, cemiyet ve realiteyle yeniden münasebetler kurmaya başlayan bu nesil günübirlik olan bütün somut realiteleri, Divân neslinin aksine başköşeye yerleştirmiştir, uhrevi ve insani olan, dünyevi bir gerçekliğin içinde tespit edilmeye çalışılmıştır.

Tanzimat'ın bu ilk neslini, eski terbiye ve devlet kalemi yetiştirmiştir. Devletle içli dışlı olan bu neslin en bariz özelliği sadık birer siyasi oluşlarıdır. Mustafa Reşit Paşa'nın Batılı tercihini, ardından idareye gelen, ihtiyatlı davranan, Âli Paşa devralıp batılılaşmayı kısmen yavaşlatınca, Tanzimat nesli muhalifini bulmuş olur (Akyüz, 1982: 12). Batılllaşmanın temposunun düşmesi bile bu nesli harekete geçirir. Kenan Akyüz bu çığırnn halka mal olduğunu söylese de gerçekte batıllış̧manın ne yüz elli yıl önce ne Cumhuriyetle ne de bugün halka mal olduğu sonucunu çıkarmak zor görünüyor. Aydınlar çevresinin gayretlerini, sürekli şüpheyle karşılayan halk hâlihazırda bile okumuşlarına güvenmediğini açık seçik gösteriyor. Ancak Avrupa Birliği söz konusu olunca, kültürel donanım ve süreç olarak kendi tercihlerinden yana bir iktidarın vitrini halkın ekseriyatını batıdan yana döndürebilmiştir.

Tanzimat nesli üç ayrı uğraşı bütünün parçaları addedip siyaset, cemiyet ve edebiyatı birlikte ele almıştır. Büyük amaç ve idealleri olan bu nesil yaptıklarını halk adına yaptıklarından halka yönelmiş, halkı aydınlatmak için halkın lisanı ile gazete çıkarmış, gazeteciliğin mimarı olmuştur. Gazeteler yoluyla hükümeti uyarma ve tenkit pozisyonunda bulunmuşlardır. İdare ile olan mücadeleleri, gazetenin sansür ve engellenmesine kadar gitmiştir (Akyüz 1982: 12). Tanzimat nesli devrin fikir akımlarına öncülük yapmış, bütün hamlelerde de ilk olmuştur. Osmanlıc1, İslamc1, Türkçü anlayışlar ayrışmadan iç içe geçmiş şekilde bu neslin fikriyatını tamamlamıştır. Zamanla bu görüşler ayrışmış ve ayrı saflar tutulmaya başlanmışırır. Bu kurtuluş reçetelerinin farkları da netleşmiştir. Bu belirginleşmeye, sosyal gelişmelerin birinci derecede etken olduğu muhakkaktır. Bu nesil edebi türlerin ilk örneklerini -tiyatro, roman, tenkit- vermiş olmakla yalnız sosyal sahada değil edebi sahada da inkılabı düşünmüşlerdir. Bu neslin şiddetli düalizmine (Garp-Şark) rağmen almış oldukları terbiye ve köklü inanç tarih şuurundan dolayı Garp'a fazla 
kapılmadıkları, bu yeni medeniyet karşısında da ezilmedikleri görülür. Kendilerinden sonraki nesillerin aşağılık kompleksi, inanç buhranı söz konusu olmadığı gibi büyük düşünen birer ideal adamı olmayı da sürdürürler. Bu nesil meşruti idare ve yan kurumların yerleştirilmesi için hayatları pahasına mücadele örneği verecek kadar kararlı ve gözü karadır (Kaplan, 1970: 28). Yine ilave etmek gerekir ki ne 2. nesil ne de ara nesil onların tavrını asla devam ettiremeyecektir. Mehmet Kaplan'in tasnifi ve adlandirması ile "Politik ve Sosyal Fikirler Devri"(Oktay 1993: 17) nin edebi sahada şiiri nesre yaklaştıran, günlük küçük şeyleri şiire sokan, sosyal meseleleri bayraklaştıran en isabetli yönlerinden biri, halkın konuştuğu lisanı, halk Türkçesini tercih etmeleridir. Bütün gelişmişliği ve yeniliğine rağmen, bu nesil eskiye bağlı kalmış, batılı anlayışların ileri safhasında yeni denemelere karşı eski olduklarını itiraf etmişlerdir (Kaplan, 1987: 21).

Tanzimat ikinci nesli Abdülhak Hamit, Recaizade Mahmut Ekrem ve Samipaşazade Sezai'nin temsil ettiği, "Hamit-Ekrem-Sezai Mektebi" de denilen nesildir. Yine M. Kaplan'ın isimlendirmesi ile "Ferdiyetçilik, büyük ihtiraslar ve 1stıraplar devri" (Kaplan, 1987: 22) diye de tanımlanabilir. $\mathrm{Bu}$ nesil her şeyden önce sosyal ve politik meselelere kayıtsız kalır. Onların zaviyesinde sanat, sosyal faydayı değil ferdi 1stırapları ele alan estetik yeterliği gaye edinen bir sahadır. Bu anlayışla hareket eden bu nesil için "sanat şahsi ve muhteremdir". Onlar 1. neslin aksine şiiri nesre tercih ederler. Bu tercihin gerektirdiği yeterli muhteva şekilde batılı şiiri kurar. Birinci neslin kükreyen mizacından uzak olan bu sanatkârlar, ferdi 1stırapların dışına çıkmamışlardır. Bu anlayışları eserlerindeki tiplere de yansıtan neslin şiirinde felsefe, aşk, tabiat âlemleri batılı bir anlayışla yer alır (Kaplan, 1987: 23). Sanatkârında üslup ve başarı artar. Sanatın, özelde edebiyatın değer hükmü ve farklı saygınlığı bu dönemde iade edilmiş olur.

Estetiğin teorisini kuran 2. nesil, gazeteciliği tamamen terk eder. Estetik anlayışı M. Naci ve arkadaşlarının tavırları ile çelişki üzerine kurulur. Batı retoriğini bu mücadele ekseninde kurarlar. Anlayış ve tutumları Servet-i Fünûn'a zemin hazırlar. Bu nesil, "Hamit ile heyecanlı bir düşünce buhranına, büyük ihtiras ve 1stırap ifadesine bürünürken Recaizâde ile daha ziyade duygusallığ1 yakalar (Kaplan, 1987: 23).

Ara nesil modern edebiyatın 3. nesli sayılabilir. Mehmet Kaplan, bu nesle "küçük ve günlük hassasiyetler devri" (Kaplan, 1987: 23) adını verir. Bu nesil Servet-i Fünûn 'a kadar "günlük küçük hassasiyetleri" realist bir yaklaşımla ele alan, kendine ait özellikleri olan Nabizâde Nazım, Mehmet Celal, Mehmet Ziver, Fazlı Necip gibi edebiyat tarihinde çok parlak yer edinemeyen isimlerden oluşur (Akyüz, 1982: 74). Bu nesle edebiyat tarihi içinde yer veren Mehmet Kaplan, genel bir temayül olan, Hamit ve Ekrem'den sonra Servet-i Fünûn'un başlatılmasını yanılgı olarak zikreder. Çünkü iki nesil arasında yaklaşık yirmi yıllık bir süre söz konusudur ve bu süre Abdülhamit idaresine tekabül eder. Bu nesil, duyuş tarzı ve üslup sahasinda edebiyatın çehresine değişiklik getirmeyi başaran 25-30 kişilik bir gruptur. Devrin en dikkate değer tarafı, gazetecilik yerine dergiciliği oldukça iyi bir aşamaya getirmiş olmasıdır. İdarenin tutumunu bir arada olmaya zorladığ 1 bu nesil Hamit, Ekrem çizgisini devam ettirir. Ancak onlarla yetinmeyip tecrübe yolu ile yeni gelen temaları işlemişlerdir. Servet-i Fünûn da hat safhaya çıkan santimantalizmin öncüsü bu nesildir. Şiirde düşünceler yerine duygu ve hayalden ibaret olan bir ruhu yaygınlaştırıp "nesir ve şiiri veremliler, hasta çocuklar fakirler, aşk 1stırabı ile inleyen, zaruret altında ezilmiş insanlar" (Kaplan, 1987: 32) edebiyatı hâline sokarlar. Gerek lisan gerekse şiirde resmin etkisinin Fikret'ten önce işlendiğine bu nesilde şahit oluruz. Yine Servet-i Fünûn'dan önce batılı bir üslubun da işlenmesi ile Servet-i Fünûn'a tesir ederler.

Modern edebiyatın 4. nesli olarak yer alan Servet-i Fünûn nesli, son yüz elli yılda oldukça etkili ve adından bahsettiren bir gruptur. Bu ortak duyuş ve üslup özelliklerine sahip topluluğun en açık farkı bedbin, bedbaht bir psikolojiyi yaşamıs olmalarıdır. Şiirlerinde ve romanlarında hayatı 1stırap kaynağ1 olarak gören iradesiz, melankolik bir nesil (Kaplan, 1987: 34) olan bu devrin sanatkârları gibi eserleri de hastalıklı ve solgun bir mahiyet arz eder. Hayattan, halktan idareden, 
ülkeden nefret eden, milletin lisanını konuşmayan, kendi dünyasını yaşayan muzdaripler devridir bu nesil (Akyüz, 1982: 79). Servet-i Fünûn nesli, Türk edebiyatının batıyı tercihinin kesin sonucudur. Doğu-Batı mücadelesinde Batı'nın galibiyet kazandığı zihniyet, tema, teknik açılardan tam Avrupai kimliğin oluştuğu bir devirdir (Kaplan, 1987: 34).

Servet-i Fünûn neslinin topluluk oluşu, ortak duyuşu birinci derecede Abdülhamit muarızlı̆̆ına dayanır. Ferdi hassasiyetleri ve bedbinliklerine dıs dünyayla olan uyumsuzlukları da eklenince, çevreyle alakayı keserler. Yalnız sanatın dünyasına, tabiata fildişi kulelerine çekilirler. Eğitim, mizaç ve kültür itibariyle tam Batılı olan bu nesil, yerel bütün değerlerle çatışma hâlindedir. Yerli eser ve isimler yerine birkaç yabancı dil bilen bu nesil batı ile sıkı irtibatını daima korumuştur. Aşırı derece bağlı olduğu Fransız edebiyatından hayal dünyası ve yeni vokabüler alır. Şiiri nesre oldukça yaklaştırır. Güzel sanatlara ehemmiyet verip estetik düşünce ve beceri olarak da oldukça başarılı olurlar.

Birinci Tanzimat neslinin aksine hemen tamamı orta tabakadan insanlardır. Papaz mekteplerinde, batılı okullarda okuyan, görev yapan bu insanlar dine tamamen bigâne kalırlar. Başıboş, sorumsuz olmalarına rağmen sistemli estetiği terk etmezler. Çıkardıkları dergiler mizanpaj olarak düzenli, konuları itibariyle sıradan ve tercümelerle doludur. Garptan sarhoşça beslenip mest olurlar (Kaplan, 1987: 35). İlk defa kadın meselesini ele alıp onlar için de hürriyet isterler. Aristokrat bir edebiyat kuran bu devir, laik düşünceyi açık olarak işleyen, maziye tamamen kapalı, fikirden ziyade romantizm ve duygusallık içinde, ağdalı bir lisanla terennüm eden bir kimliğe sahiptir (Kaplan, 1987: 41).

$\mathrm{Bu}$ nesli bir arada tutan şeyin Abdülhamit muarılı̆̆̆ olduğunun delili olarak şiddetle istedikleri hürriyete kavuşunca dăğllıp gitmelerinin gösterilmesi yanlış olmaz. Zaten onları bir araya getiren biraz da tesadüflerdir (Kaplan, 1970: 17). Tesadüfün mimarı, mıknatısı Recaizade, mekânı ise çoğunlukla Servet-i Fünûn mecmuası olmuştur. Aslında bu nesil çok farklı karakterlerden oluşmuştur.

Buraya kadar oluşan nesilleri Mehmet Kaplan'ın ifadesiyle özetlersek "N. Kemal'in büyük vatan, hürriyet, meşrutiyet gibi prensipleri, düşünceleri I. merhaleyi; Hamit'in büyük ihtiras ve felsefeleşmiş düşünceleri, 1stırapları II. merhaleyi; Recaizâde'nin santimantalizmi ile ara neslin küçük duygu tasvirlerine inhisar eden şiirleri III. merhalenin başlangıcını gösterir." (Kaplan, 1970: 18).

Servet-i Fünûn'dan sonra kısa süre hayatiyetini sürdüren Fecr-i Âti topluluğu bir nesil karakteri göstermez. II. Meşrutiyet ve getirdiği kargaşa ortamı, ardından patlak veren ardı arkası gelmez savaş ve felaket yılları, yeni bir nesli pişirir, şekillenmesinde etkili olur. Bu nesil Millî edebiyat topluluğunu ve Cumhuriyet'e uzanan yeni yapılanmayı kuran nesildir. Cumhuriyet nesli, Osmanlının tükenişi ve yeni millî devletin kuruluşunun ortak paydasıdır. Öte yandan bu dönem nesli inkıraz sonrası istiklal mücadelesi, bozkır ruhunun Ankara'da yeniden doğuşu, yeni bir neslin İstanbul'a karşı ortaya çıkışıdır (Kaplan, 1970: 18).

Cumhuriyet nesli; Âkifin maneviyatı, Gökalp'in milliyetçiliği, Y. Kemal'in tarih ve coğrafya şuuruyla beslenmiş, millî mücadele tecrübesi de bütün nesillerden daha fazla reaksiyon almalarına sebep olmuştur. Cumhuriyet'e kadar az çok eskiye, değer yargılarına bağlllık söz konusuyken bu nesil maziye köklü bir tepki olarak şekillenmiştir. Bu tepki Cumhuriyet ideolojisinin hem sebebi hem de sonucu olur.

Mehmet Kaplan, Cumhuriyet neslini iki kısımda ele alarak II. Dünya Harbi'ne kadar olan kısım ve sonrası diye sınıflar. Ancak bu devri üç kısımda ele almak doğru olur zannediyorum. Cumhuriyet'i II. Meşrutiyet yıllarından kopuk ele almak doğru olmayacağı gibi bu nesille aynı saymak da doğru olmaz. Meşrutiyetten Cumhuriyet'e, harp veya felaketler nesli, ardından millî devlet nesli, sonrası ise zengin, renkli, çok sesli nesiller devri olarak ele alınabilir. Cumhuriyet öncesi nesil büyük felaketler, zaruretler ve savaşın pişirdiği nesildir. Bu nesil bir yandan millî ruhu 
canlı tutmak, insanları zafere inandırmak yolunda eserler verirken mücadelenin içinde bizzat bulunurlar. Yeni devletin yapısına da harcı koyarlar. Bütün farklılıklarına rağmen, bu neslin ortak yönü kurtuluşa gönül vermek, mücadele etmek, yepyeni bir devlet kurmaya azmetmektir. Bu nesil farklılıklarıyla, Cumhuriyet neslinin fikri yönelişlerine de zemin hazırlayacaktır. Yaklaşık 70 yıllık neslin fikir temelleri bu devirde atılır. İslamcı, Türkçü, Garpçı düşünceler Tanzimat ile başlamakla beraber, reçetelerinin daha net belirmesi II. Meşrutiyet yıllarına uzanır. Cumhuriyet nesli, Gökalp ve arkadaşlarının arzularına cevap vermiş olmakla beraber, sonraları bu düşüncenin mensuplarını da rahatsız etmiş, Âkif anlayışına -kısmen Yahya Kemal anlayışına da- çoğunlukla karşıt tavır almiştır.

II. Cihan Harbi'nden önceki Türkiye; tek parti, tek şef, tek ideoloji esasına dayanır. Bu devrin bütün kimliği, rengini Cumhuriyet ideolojisinden alır. Müdahaleci, yönlendirici, zorlayıc1 bir yöntemle tek tip nesil imaline Batılı pozitivist yapısında faydalanmak isteyen nesil Marksist çizgisine faaliyet alanını ancak İnönü şefliğinde bulur. Atatürk onlara da firsat vermez. Ancak bu yeni, devlet güdümlü neslin oturaklı tavır sergilemekten ziyade sermayesi; eskiye, maziye sövüp yeniyi alkışlamaktan başka bir şey olmaz.

Cumhuriyet nesli bütün programlılı̆̆ına rağmen kendi içinde homojen bir karakteri kuramamıştır. Batıli tercihine rağmen bu nesil, Osmanlı müesseselerinin, mektep ve medreselerinin yetiştirdiği insanlardı. Yeni inkâr ve imar planında ikilemler yaşamaktan kurtulamadılar. Yeni yapının bizzat mimarı olan Atatürk bile bu çelişkileri yaşadı. Türk tarihinin büyük simalarına hayran olup onlara düşmanlıktan da geri kalmadı. Alaturka musikiden çok hoşlanıp alafranga musikiyi yerleştirmenin mücadelesini verdi (Akyüz, 1982: 35). Tarihi efsanelere dayanmaya; Eti, Sümer tarihini canlandırıp Türk'e menşe aramaya çalışılır. Yapılan inkılâplar milleti kendine benzemeyecek aşamaya sürükler. Yepyeni bir millet yarattığı iddiasında olan yeni ideoloji, edebi sahada da yeni değerlerin müdafi nesiller yetiştirir. Tarih ve kültür yanında din de nasibini alır. Cumhuriyet nesilleri yer yer din düşmanlığını sermaye olarak -halka rağmen- kullanır. Âkifte tek çözüm Ziya Gökalp ve Yahya Kemal'de en azından geleneğin mutlak parçası olan din; yerini "yaşama sevinci"ne, kitap ise Andre Gide'nin "Dünya Nimetleri"ne bırakır. Aşk ise "şehvete, bayağıllğg" bırakır" (Kaplan, 1987: 38). Kadın birdenbire orta malı hâline getirilir. Evlilik alay konusudur. Zinaya ait tercümelerdeki gibi kadını arkadaş ve meta olarak algılamaya başlarlar. Erozyona uğrayan değerler yeni bir milliyetçilik adına bürünür, Atatürk milliyetçiliği zamanla beynelmilelci yapıya dönüşür (Kaplan, 1985: 45).

Aslında materyalizme karşı olan yeni anlayış temelinde yatan pozitivist yapı ile komünizme zemin hazırlar. Komünizm ise Rus yayılmacilığı güdümüne girer ve yayılmakta gecikmez. Nazım Hikmet, Sabahattin Ali gibi isimler bu ideolojiyi yaygınlaştırmaya yeni bir neslin peydahlanmasına çalışırlar. İnönü devrinde ise büsbütün meydanı kaplarlar. Birbirine yakın iki grup görünümünde olan Batıcı ve sosyalist nesil, aşama aşama aynı çizgiye gelir.

Cumhuriyet dönemi zenginliği, karmaşa ve çok sesliliği esas alınca, alt şubeler çok daha fazlalaşabilir. İslamcı ve milliyetçi şubeler ise kısmi serbestî fırsat tanıyacaktır. Aynı ülke, aynı toprak ve idare, aynı zaman dilimi birbirinden uzak, farklı hatta düşman nesillere sahne olacaktır. Kesin ayrışmalar ise 1948'den sonra belirir. Mehmet Kaplan bu aşamaları üç hadiseye bağlar:

1- Türkiye'nin hür milletler camiasına kabulü,

2- Komünizm'in cesur ve yaygı̀n hâle gelmesi,

3- Dine ve tarihe dönüş.

Bu nesillerin yeşermesinde -farklılıklara rağmen- 1950 sonrası çok partili dönemin, Batılı sermayenin çok açık tesiri vardır. Türkiye bir yandan komünizm ajan ve yerli iş birlikçilerinin bir yandan batı sömürgesinin faaliyet alanı olurken beklenmedik bir hıla kendine, Millî olana, tarihe, dine dönüş yaşar. Bu yenilikler yalnız Millî düşünceye değil öte yandan, demokratik yapı adına 
getirdiği proletarya, şehirleşme, sefalet ve sosyal dengelerin sarsılmasıyla, sol nesillere de yeni zeminler hazırlamış olur. Cahil Anadolu insanı ani şehirleşmeye, gecekondulara yığılırken istismara uğrar.

Güdülerle yaşayan neslin yerine -Orhan Veli, Cahit Sttkı, Bedri Rahmi, Sait Faik felsefeleri yerine- Marksizme rağmen, İslami idrake dönük nesiller yeniden oluşmaya başlar (Tanpınar, 1985:87).

Cumhuriyet nesli, önceleri oldukça sağlam halk lisanına dayalı bir Türkçe ile eserler vermiş, ancak zamanla sadelik öz Türkçecilik ve eski düşmanlığı adına lisanı güdükleştirmenin de öncülügünü yapmıştır. Bu politikaya sonuna kadar sadık kalan sol, zamanla sol-Kemalizm terkibini (Tuncer, 1992:98) kurmakta zorluk çekmemiştir. Aynı kitle içinde sosyal gerçekçilik yoluyla edebî ekollere yol açan edipler, sol yerine demokrasi, laiklik ve Kemalizmi de istedikleri gibi yorum ve kullanma hakkını ellerinde bulundurmuşlardır. Garip şiiri solun sahiplenmesine rağmen, bir nevi Marksist estetiğin esnetilmesi, resmî ideolojinin edebiyatı olur. II. Yeni halis sanatın, gizem ve estetiğin yeniden hayatiyet bulmasıdır. Öte yandan Âkif, Necip Fazıl çizgisinin Sezai Karakoç yorumundan bir İslami sanat anlayışının da Cumhuriyet nesilleri arasında yerini aldığ1 görülür.

Cumhuriyet neslini, Atatürk Türkiye'sinde açılan okulların, batıya gönderilen öğrencilerin yanında, 40'lı yıllarda tercüme faaliyetleri ve açılan köy enstitülerinin de yetiştirdiği dikkatten uzak tutulmamalıdır.

\section{Sonuç}

Batılılaşma Devri, Arayışlar Devri, Modern Edebiyat, gibi birçok isimlendirilmeye tabi tutulan son yüz elli yıllık edebiyatımızda en dikkati çeken husus, oldukça fazla ekol, isim, akım ve dolayısıyla nesle yer vermesidir. Sosyal hayatın hızlı değişimi, aşırı hareketlilik, binlerce yıla sığacak hadiselerin yüz yıla sı̆̆dırılması, oldukça karmaşık, karmaşık olduğu kadar da çeşitli fikirlere sebep olmuştur. İki farklı dünyanın (doğu-batı) münasebeti yepyeni insan, eğitim ve öğretim, farklı bir tüketim anlayışı doğurmuş, kâinatı algılama biçimi köklü değişim geçirmiştir. Bu durum son yüzyılda çok daha hız kazanmış, insanlık tarihinde az rastlanır değişimlerden en fazla nasip de bize düşmüştür. Birbirine zıt dünya görüşleri, fikir akımları, felsefi tercihler, ideolojiler, izlenimler çağ1 olan bu asırda bütün bunlar yetmiyormuş gibi insanlar idare ile de büyük problem yaşamıștır. Kitlesel hareketler kalabalıkları peşine takınca her kalabalık bir nesle mensup olmuştur. Bütün bunlar dikkate alınınca, çok fazla nesille yüz yüze kalmış oluşumuzu daha iyi anlarız. Aynı şartlar, aynı okullar, aynı ideolojiler neticesi bunca çeşitliliğge daha doğrusu kargaşaya sebep olurken tabiî ilimlerin metotlarının insani ilimlerde ne kadar ters sonuç verdiği de ortaya çıkmıştır.

\section{Kaynakça}

AKYÜZ, Kenan (1982). Modern Türk Edebiyatınn Ana Çiəgileri, Ankara: İnk1lap Kitabevi.

KAPLAN, Mehmet (1985). Edebiyat Üzerine Araștırmalar, İstanbul: Dergâh Yayınlar1

KAPLAN, Mehmet (1970). Nesillerin Rubu, İstanbul: Hareket Yayınlar1.

KAPLAN, Mehmet (1987). Tevfik Fikeret (Devir-Şabsiyet-Eser), İstanbul: Dergâh Yayınları.

OKTAY, Ahmet (1993). Cumburiyet Dönemi Türk Edebiyatı (1923-1950), Ankara: Kültür Bakanlığı Yayınları.

TANPINAR, Ahmet Hamdi (1985). 19. Asır Türk Edebiyatı Taribi, İstanbul: Çağlayan Yayınları.

TUNCER, Hüseyin (1992). Arayışlar Devri Türk Edebiyatı I-II, İzmir: Akademi Kitabevi. 